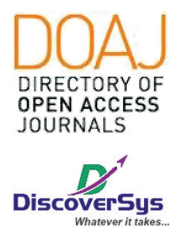

Published by DiscoverSys

\section{Analisis tingkat pengetahuan mahasiswa program studi pendidikan dokter tahun ajaran 2017-2018 Universitas Udayana tentang prescribing error}

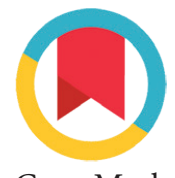

CrossMark

\author{
Nabila Putri Rachmawati, ${ }^{1 *}$ Desak Ketut Ernawati, ${ }^{2}$ I Gusti Ayu Artini ${ }^{2}$
}

\section{ABSTRACT}

Introduction: Prescribing Errors is a failure in the treatment process leading to or potentially harmful to the patient, this error most often occurs although it can be prevented. The incidence of prescribing errors continues to increase from year to year, but data in Indonesia that discusses the level of knowledge of medical students about prescribing errors is still small. The purpose of this study is to determine the level of knowledge of medical student study program 2017-2018 academic year at Udayana University Denpasar about prescribing errors.

Method: This research is a descriptive cross sectional study conducted at the Medical Faculty Udayana University Sudirman Campus Denpasar. Data obtained in the form of primary data questionnaire. Data were analyzed using software computer.

Result: The results showed that the most gender are women of 68 students (66\%). The largest proportion of age is $19-20$ years old number of 52 students (52\%). Groups of semesters 1, 3, 5 and 7 obatined a similar proportion of 25 students (25\%). The level of students' knowledge of prescribing case study is classified into moderate category with mean 3,7-7,1 of 67 students (67\%). The number of correct answers in identifying type of error from 3 prescriptions is in the case of the first prescription, the 3rd semester student who is able to identify the prescribing error, with the type of mistake that is wrong dose as many as 14 students (35,9\%) with p value $=0,066$ and wrong dosage form as 21 students $(39,6 \%)$ with $p$ value $=0.000$. In the case of the second prescriptions, 7th semester students were able to identify the prescribing error, with the type of mistake that is wrong dose as many as 13 students $(41,9 \%)$ with $p$ value $=0,005$ and wrong dosage form as 22 students $(36,7 \%)$ with $p$ value $=0.000$. In the case of the third prescriptions, the 3 rd semester students were able to identify the prescribing error, with the type of mistake that is the wrong indication of the drug as many as 15 students $(62,5 \%) p$ value $=0.000$.

Conclusion: In this research, it can be concluded that the knowledge level of the majority students is in moderate levelabout 67 (67\%). While the remaining respondents good knowledge level as much as 7 (7\%) and bad knowledge is as much as 26 (26\%).

Keywords: Knowledge, Medical Student, Prescribing Errors (PE)

Cite This Article: Rachmawati, N.P., Ernawati, D.K., Artini, I.G.A. 2019. Analisis tingkat pengetahuan mahasiswa program studi pendidikan dokter tahun ajaran 2017-2018 Universitas Udayana tentang prescribing error. Intisari Sains Medis 10(1): 148-154. D0I: 10.1556/ism.v10i1.323

\title{
ABSTRAK
}

Latar Belakang: Prescribing Errors merupakan kegagalan dalam proses pengobatan yang mengarah atau berpotensi membahayakan pasien, kesalahan ini paling sering terjadi meskipun dapat dicegah. Angka kejadian prescribing errors terus meningkat dari tahun ke tahun, namun data di Indonesia yang membahas mengenai tingkat pengetahuan mahasiswa kedokteran tentang prescribing errors masih sedikit. Tujuan penelitian ini yaitu untuk mengetahui tingkat pengetahuan mahasiswa program studi pendidikan dokter tahun ajaran 2017-2018 di Universitas Udayana Denpasar tentang prescribing errors.

Metode: Penelitian ini merupakan penelitian deskritif cross sectional yang dilakukan di Fakultas Kedokteran Universitas Udayana kampus Sudirman Denpasar. Data yang diperoleh berupa data primer kuesioner. Data dianalisis dengan menggunakan software computer. Hasil: Hasil penelitian menunjukkan bahwa jenis kelamin terbanyak yaitu perempuan sejumlah 66 mahasiswa (66\%). Proporsi umur terbanyak yaitu 19-20 tahun sejumlah 52 mahasiswa (52\%). Kelompok semester 1, 3, 5 dan 7 diperoleh jumlah proporsi yang serupa yaitu masing-masing sebesar 25 mahasiswa (25\%). Tingkat pengetahuan mahasiswa terhadap studi kasus peresepan tergolong ke kategori sedang dengan rerata 3,7 - 7,1 sejumlah 67 mahasiswa (67\%). Jumlah jawaban yang benar dalam mengidentifikasi jenis kesalahan dari 3 kasus resep yaitu pada kasus resep pertama, mahasiswa semester 3 yang mampu dalam mengidentifikasi kesalahan resep, dengan jenis kesalahan yaitu salah dosis sebanyak 14 mahasiswa $(35,9 \%)$ dengan nilai $p=0,066$ dan salah bentuk sediaan sebanyak 21 mahasiswa $(39,6 \%)$ dengan nilai $p=0,000$. Pada kasus resep kedua, mahasiswa semester 7 yang mampu dalam mengidentifikasi kesalahan resep, dengan jenis kesalahan yaitu salah dosis sebanyak 13 mahasiswa $(41,9 \%)$ dengan nilai $p=0,005$ dan salah bentuk sediaan sebanyak 22 mahasiswa $(36,7 \%)$ dengan nilai $p=0,000$. Pada kasus resep ketiga, mahasiswa semester 3 yang mampu dalam mengidentifikasi kesalahan resep, dengan jenis kesalahan yaitu salah indikasi obat sebanyak 15 mahasiswa (62,5\%) nilai $p=0,000$.

Simpulan: Pada penelitian ini dapat disimpulkan tingkat pengetahuan mahasiswa mayoritas berpengetahuan sedang yaitu sebanyak 67 (67\%). Sedangkan responden sisanya berpengetahuan baik sebanyak 7 (7\%) dan berpengetahuan buruk sebanyak 26 (26\%). 
Kata kunci: Pengetahuan, Mahasiswa Kedokteran, Prescribing Errors (PE)

Cite Pasal Ini: Rachmawati, N.P., Ernawati, D.K., Artini, I.G.A. 2019. Analisis tingkat pengetahuan mahasiswa program studi pendidikan dokter tahun ajaran 2017-2018 Universitas Udayana tentang prescribing error. Intisari Sains Medis 10(1): 148-154. D0I: 10.1556/ism.v10i1.323

\section{PENDAHULUAN}

Pengetahuan adalah hasil dari mengetahui dan terjadi setelah melakukan penginderaan terhadap suatu objek. Pengetahuan, aturan, tindakan dan memori merupakan ketegori penting dalam hal penulisan resep. Keempat kategori tersebut merupakan dasar dari penulisan resep yang harus dimiliki oleh seorang praktisi kesehatan. Jika salah satu dari keempat kategori tersebut tidak dimiliki, dapat mengakibatkan terjadinya kesalahan pengobatan dalam hal prescribing errors (kesalahan peresepan) (Warholak dkk, 2011). Akibatnya dapat menimbulkan dampak yang mengarah ke kesalahan dosis, rute obat, serta interaksi obat yang salah. ${ }^{1}$

Interaksi obat dapat menghasilkan efek yang memang dikehendaki (Desirable Drug Interaction), atau efek yang tidak dikehendaki (Undersirable/ Adverse Drug Interaction $=A D I s$ ) yang lazimnya menyebabkan efek samping obat dan toksisitas karena meningkatnya kadar obat di dalam plasma, atau sebaliknya menurunnya kadar obat dalam plasma yang menyebabkan hasil terapi menjadi tidak optimal. Di Amerika Serikat, insidens interaksi obat yang mengakibatkan reaksi efek samping sebanyak $7,3 \%$ terjadi di rumah sakit, lebih dari $88 \%$ terjadi pada pasien geriatric di rumah sakit, lebih dari $77 \%$ terjadi pada pasien HIV yang diobati dengan obat-obat penghambat protease. ${ }^{2}$

Laporan dari Institute of Medicine (IOM) menyatakan bahwa perawatan kesehatan di Amerika Serikat tidak aman, dan dilaporkan bahwa paling sedikit 44.000 bahkan 98.000 pasien meninggal di rumah sakit dalam satu tahun akibat dari medical errors yang sebetulnya dapat diminimalisir. Kuantitas ini melebihi kematian akibat kecelakaan lalu lintas, kanker payudara dan AIDS. ${ }^{3}$ Prescribing errors merupakan salah satu jenis dari medication error (ME), yang meliputi prescribing (peresepan), dispensing (penyiapan), drug administration (pemberian obat). ${ }^{4}$ Dari semua kesalahan pengobatan, secara umum prescribing errors (PE) yang lebih banyak terjadi meskipun dapat dicegah. ${ }^{5}$ Sehingga PE merupakan penyebab bahaya yang penting bagi pasien, dan menjadikannya area prioritas untuk keselamatan pasien.

Sebuah studi dari Amerika Serikat menyebutkan bahwa sekitar 900 kesalahan pengobatan (ME) pada anak-anak, 30\% adalah kesalahan peresepan (PE), $25 \%$ adalah kesalahan penyiapan hingga penyerahan obat (DE) dan $40 \%$ adalah penggunaan obat (AE). Dalam salah satu studi menyebutkan paling umum yang terjadi pada kesalahan peresepan (PE) adalah menulis dosis yang salah. ${ }^{6}$

Angka kejadian medication error meningkat menurut kajian Hamde Nazar dkk dikarenakan kesalahan pengobatan dibuat oleh dokter yang baru saja lulus dari masa studinya. Pada kenyataannya $75 \%$ dari semua penulisan resep rawat inap ditulis oleh lulusan baru (Nazar dkk, 2015). Laporan frekuensi dari PE bervariasi antara 39\% dan 74\% dari semua ME. Sebuah survey dari Italy menunjukkan dari segi penulisan resep bahwa 1 dari 4 resep tidak sepenuhnya lengkap atau yang tidak terbaca. Secara keseluruhan 23,9\% dari resep yang terbaca dan 29,9\% dari resep yang tidak lengkap. ${ }^{7}$

Berdasarkan data yang sudah dikumpulkan dan kenyataan yang ada bahwa masih terdapat kesalahan dalam penulisan resep dari segi tulisan atau dalam segi mempraktikkan format menulis resep dengan tepat dikalangan dokter termasuk dokter yang baru saja lulus dari masa studinya. Sehingga, peneliti tertarik untuk melakukan penelitian tentang analisis tingkat pengetahuan mahasiswa kedokteran Universitas Udayana tentang prescribing errors.

\section{METODE PENELITIAN}

Penelitian ini merupakan penelitian deskritif cross sectional yang dilakukan di Fakultas Kedokteran Universitas Udayana kampus Sudirman Denpasar. Sampel penelitian ini yaitu mahasiswa program studi pendidikan dokter semester ganjil tahun ajaran 2017-2018 Fakultas Kedokteran Universitas Udayana Denpasar. Dan teknik pengambilan sampel yang digunakan pada penelitian ini adalah proportionate stratified random sampling.

Data yang diperoleh berupa data primer yaitu kuesioner. Kuisioner dirancang untuk menilai kemampuan mahasiswa kedokteran dalam mengidentifikasi kesalahan resep obat yang digunakan pada penelitian ini. Mahasiswa hanya diberikan waktu 10 menit untuk mengerjakan kuesioner yang telah disebarkan dan tanpa melihat sumber untuk mengerjakannya. Penelitian ini telah disetujui oleh Komisi Etik Penelitian Fakultas Kedokteran Universitas Udayana.

Kuesioner terdiri dari 3 resep dengan pasien samaran dan tambahan informasi terkait pasien (nama, tanggal kelahiran, berat badan, diagnosis untuk di bawah pengawasan resep, alergi obat, dan pengobatan saat ini). Jenis kesalahan resep yang disajikan dalam kuesioner termasuk nama obat 
yang salah dan perhitungan dosis yang salah tercantum pada (Lampiran 1), dari sini dapat membantu dalam pengambilan keputusan bagi responden. Resep 1 berisi sebuah kesalahan perhitungan untuk populasi berisiko tinggi (yaitu, pediatri) dan bentuk sediaan obat. Di contoh kuesioner pemberian zinc dengan dosis $10 \mathrm{mg}$ pada usia 12 bulan. Seharusnya dosis zinc pada usia lebih dari 6 bulan yaitu $20 \mathrm{mg}$, dosisnya jauh lebih rendah daripada yang direkomendasikan (yaitu $10 \mathrm{mg}$ ). Resep 2 berisi kesalahan interaksi dua obat yang diresepkan. Resep 3 berisi salah indikasi dan lama terapi obat antibiotiK.

Data dianalisis dengan menggunakan software computer. Selanjutnya dilakukan pengolahan data, kemudian disajikan dalam bentuk tabel, diagram pie, dan diagram bar.

Tabel 1 Distribusi Frekuensi Karakteristik Demografi Responden

\begin{tabular}{lcc}
\hline Karakteristik & $(\mathbf{N}=\mathbf{1 0 0})$ & (\%) \\
\hline Jenis Kelamin & 34 & 34,0 \\
Laki-laki & 66 & 66,0 \\
Perempuan & & \\
Umur & 4 & 4,0 \\
$<$ 18 tahun & 23 & 23,0 \\
18 tahun & 52 & 52,0 \\
19-20 tahun & 21 & 21,0 \\
$>$ 20 tahun & & \\
Semester & 25 & 25,0 \\
Semester 1 & 25 & 25,0 \\
Semester 3 & 25 & 25,0 \\
Semester 5 & 25 & 25,0 \\
Semester 7 & & \\
\hline
\end{tabular}

Tabel 2 Rerata Total Skor Jawaban yang Benar Disetiap Kelompok Semester

\begin{tabular}{lccc}
\hline Semester & Rerata & n & Std. Deviasi \\
\hline Semester 1 & 2,96 & 25 & 1,859 \\
Semester 3 & 6,40 & 25 & 0,957 \\
Semester 5 & 3,80 & 25 & 2,217 \\
Semester 7 & 6,00 & 25 & 1,414 \\
Total & 4,79 & 100 & 2,203 \\
\hline
\end{tabular}

Tabel 3 Presentase Tingkat Pengetahuan Mahasiswa Terhadap Studi Kasus Peresepan

\begin{tabular}{lcc}
\hline Tingkat Pengetahuan & Frekuensi & Persentase (\%) \\
\hline Baik $\geq 7,2$ & 7 & 7,0 \\
Sedang $3,7-7,1$ & 67 & 67,0 \\
Buruk $\leq 3,6$ & 26 & 26,0 \\
Total & 100 & 100 \\
\hline
\end{tabular}

\section{HASIL}

Dari 100 kuesioner yang disebarkan, 100 diantaranya kembali (100\% response rate). Tingkat respon dari masing-masing kelompok semester meliputi: 25 dari 242 mahasiswa semester 1,25 dari 241 mahasiswa semester 3, 25 dari 246 mahasiswa semester 5, 25 dari 247 mahasiswa semester 7. Sejumlah 100 responden yang diteliti pada mahasiswa program studi pendidikan dokter fakultas kedokteran universitas udayana di tahun ajaran 2017-2018 terhadap prescribing error.

\section{Demografi Responden}

Pada Tabel 1 menunjukkan karakteristik demografi responden berdasarkan jenis kelamin cenderung lebih banyak perempuan (66\%) dibandingkan dengan laki-laki (34\%). Berdasarkan rentang umur mahasiswa program studi pendidikan dokter diperoleh umur 19-20 tahun merupakan paling tinggi jumlahnya yaitu sebesar 52\%. Selanjutnya diikuti rentang umur $>20$ tahun sebesar $21 \%$ kemudian rentang umur 18 tahun sebesar $23 \%$ dan rentang umur $<18$ tahun sebesar $4 \%$. Kemudian pada kelompok semester 1, 3, 5 dan 7 diperoleh jumlah presentase yang serupa yaitu masing-masing sebesar $25 \%$.

\section{Perhitungan Rata-rata Tingkat Pengetahuan Mahasiswa Terhadap Studi Kasus Tentang Peresepan}

Pada Tabel 2 menunjukkan bahwa hasil analisis didapatkan rata-rata total skor setiap kelompok semesternya adalah 4,79 yang kemudian dibulatkan menjadi 4,8 dan total sampel penelitian yaitu 100 orang dengan standar deviasi 2,203 yang kemudian dibulatkan menjadi 2,2.

Skor tingkat pengetahuan dapat dilihat dari jumlah jawaban benar $(\Sigma) \pm$ SD. Jika mahasiswa mampu menjawab semua pertanyaan kuesioner dengan benar, total skor mahasiswa adalah 10. Dari hasil perhitungan seperti Tabel 2 rerata total skor tingkat pengetahuan yaitu 4,8 $\pm 2,2$ sehingga dapat ditentukan kategori tingkat pengetahuan mahasiswa tentang kasus peresepan jika:

1. Tingkat Pengetahuan Baik: $\geq 7,2$

2. Tingkat Pengetahuan Sedang : 3,7 - 7,1

3. Tingkat Pengetahuan Buruk $: \leq 3,6$

\section{Presentase Tingkat Pengetahuan Mahasiswa Terhadap Studi Kasus Tentang Peresepan}

Pada Tabel 3 dapat dilihat bahwa dari total responden sebesar 100 orang yang mengisi kuesioner, mayoritas memiliki kategori tingkat pengetahuan sedang yaitu $67 \%$ dan minoritas memiliki kategori 
Tabel 5 Distribusi Jumlah Jawaban yang Benar pada Studi Kasus Peresepan

\begin{tabular}{|c|c|c|c|c|c|c|c|c|c|c|}
\hline \multirow[b]{2}{*}{ No } & \multirow[b]{2}{*}{ Pertanyaan } & \multicolumn{2}{|c|}{ Semester $1(n=25)$} & \multicolumn{2}{|c|}{ Semester $3(n=25)$} & \multicolumn{2}{|c|}{ Semester $5(n=25)$} & \multicolumn{2}{|c|}{ Semester $7(n=25)$} & \multirow[b]{2}{*}{ Nilai p } \\
\hline & & $\mathbf{n}$ & $\%$ & $\mathbf{n}$ & $\%$ & $\mathbf{n}$ & $\%$ & $\mathbf{n}$ & $\%$ & \\
\hline 1 & Analisis Resep 1 & 16 & 20,8 & 25 & 32,5 & 14 & 18,2 & 22 & 28,6 & 0,000 \\
\hline 2 & Salah Dosis & 9 & 23,1 & 14 & 35,9 & 5 & 12,8 & 11 & 28,2 & 0,066 \\
\hline 3 & Salah Bentuk Sediaan & 5 & 9,4 & 21 & 39,6 & 11 & 20,8 & 16 & 30,2 & 0,000 \\
\hline 4 & Analisis Resep 2 & 14 & 16,1 & 25 & 28,7 & 23 & 26,4 & 25 & 28,7 & 0,000 \\
\hline 5 & Interaksi Obat & 5 & 45,5 & 0 & 0 & 6 & 54,5 & 0 & 0 & 0,006 \\
\hline 6 & Salah Dosis & 6 & 19,4 & 10 & 32,3 & 2 & 6,5 & 13 & 41,9 & 0,005 \\
\hline 7 & Salah Bentuk Sediaan & 1 & 1,7 & 21 & 35,0 & 16 & 26,7 & 22 & 36,7 & 0,000 \\
\hline 8 & Analisis Resep 3 & 14 & 20,0 & 23 & 32,9 & 11 & 15,7 & 22 & 31,4 & 0,000 \\
\hline 9 & Salah Lama Terapi & 2 & 7,1 & 7 & 25,0 & 3 & 10,7 & 16 & 57,1 & 0,000 \\
\hline 10 & Salah Indikasi & 2 & 8,3 & 15 & 62,5 & 4 & 16,7 & 3 & 12,5 & 0,000 \\
\hline
\end{tabular}

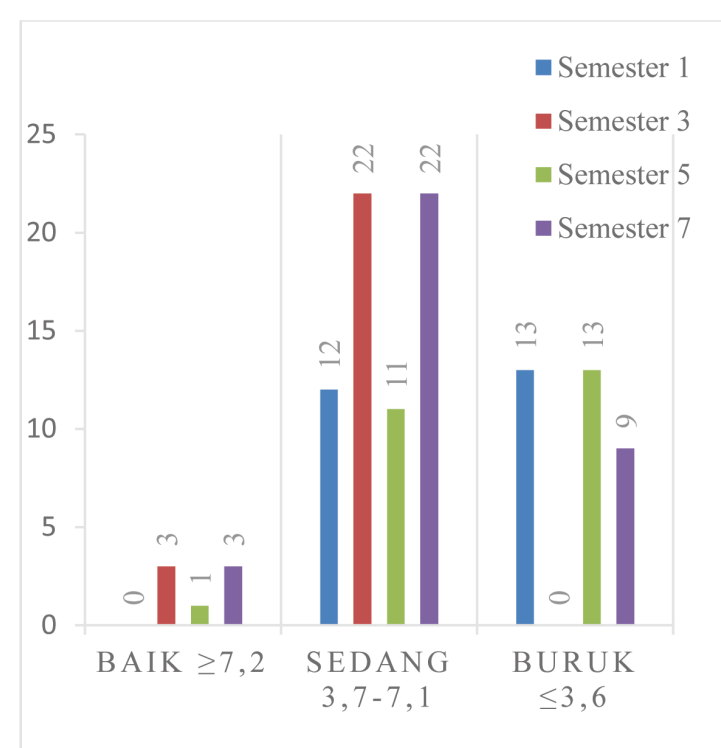

Gambar 1 Distribusi Frekuensi Tingkat Pengetahuan Berdasarkan Kelompok Semester

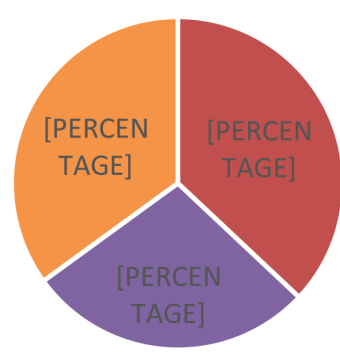

- Kuliah

Peresepan

Diperbanyak

- Latihan

Peresepan

Mandiri

- Peresepan

Setiap Block

Gambar 2 Distribusi Frekuensi Pendapat dari Pertanyaan Terbuka Pengetahuan Mahasiswa Terhadap Studi Kasus Peresepan tingkat pengetahuan baik yaitu 7\%. Sisanya memiliki kategori tingkat pengetahuan yang buruk yaitu $26 \%$.

\section{Distribusi Frekuensi Tingkat Pengetahuan Mahasiswa Terhadap Studi Kasus Tentang Peresepan Berdasarkan Kelompok Semester}

Berdasarkan Gambar 1 dapat dilihat hasil penelitian menunjukkan bahwa mahasiswa semester 3 dan semester 7 lebih dominan masuk kategori tingkat pengetahuan sedang dengan masing-masing berjumlah 22 orang dari jumlah sampel semester 3 sebanyak 25 orang dan semester 7 sebanyak 25 orang. Dibandingkan dengan yang lainnya semester 5 paling sedikit masuk kategori tingkat pengetahuan sedang yaitu 11 orang dari jumlah sampel ( $\mathrm{n}=25$ orang). Kemudian pada kategori tingkat pengetahuan baik mahasiswa semester 3 dan semester 7 lebih dominan dengan jumlah masing-masing yaitu 3 orang dari jumlah sampel di semester 3 adalah 25 orang dan semester 7 adalah 25 orang. Kemudian pada kategori tingkat pengetahuan buruk mahasiswa semester 1 dan semester 5 lebih dominan dengan jumlah masing-masing adalah 13 orang dari jumlah sampel di semester 1 sebanyak 25 orang dan semester 5 sebanyak 25 orang.

\section{Distribusi Jumlah Jawaban yang Benar dalam Identifikasi Jenis Kesalahan Resep Di Setiap Kelompok Semester}

Kuesioner tentang tingkat pengetahuaan prescribing error (kesalahan resep) yang disebarkan pada mahasiswa program studi pendidikan dokter berisi tiga kasus peresepan dan satu pertanyaan terbuka yang jawabannya berisi tentang pendapat dari mahasiswa program studi pendidikan dokter. Dari 
tiga kasus peresepan terdapat 10 butir jawaban, secara terperinci tiap butir jawaban benar akan dijabarkan dalam bentuk jenis kesalahan resep yang disajikan dalam Tabel 4.

Pada Tabel 4 hasil penelitian menunjukkan bahwa presentase kesalahan resep yang diidentifikasi dengan benar memiliki perbedaan signifikan dimasing-masing kelompok semester yang dapat dilihat dari nilai p-nya. Butir-butir pertanyaan dari kuesioner akan dijelaskan secara detail di bawah ini.

Untuk kasus analisis resep 1 tentang salah dosis dan bentuk sediaan yang melibatkan pasien umur 12 tahun dengan diagnosis diare. Pada pertanyaan pertama di kasus analisis resep 1 mahasiswa semester 3 paling banyak menjawab benar yaitu 25 orang $(32,5 \%)$ dengan memiliki nilai $\mathrm{p}=$ 0,000 . Sedangkan pada pertanyaan kedua tentang salah dosis, mayoritas mahasiswa semester 3 yang menjawab benar yaitu 14 orang $(35,9 \%)$ dan minoritas mahasiswa semester 5 sejumlah 5 orang $(12,8 \%)$ dengan memiliki nilai $\mathrm{p}=0,066$. Sementara pada pertanyaan ketiga tentang salah bentuk sediaan, mayoritas mahasiswa semester 3 yang menjawab benar yaitu 21 orang $(39,6 \%)$ dengan nilai $p=0,000$ dan minoritas mahasiswa semester 1 sejumlah 5 orang $(9,4 \%)$.

Untuk kasus analisis resep 2 tentang interaksi obat, salah dosis dan salah bentuk sediaan yang melibatkan pasien umur 30 tahun dengan diagnosis infeksi saluran kemih dan gastritis. Pada pertanyaan keempat di kasus analisis resep 2 mahasiswa semester 3 paling banyak menjawab benar yaitu 25 orang $(28,7 \%)$ dengan nilai $\mathrm{p}=0,000$. Sedangkan pada pertanyaan kelima tentang interaksi obat dengan nilai $\mathrm{p}=0,006$ yang mayoritas mahasiswa semester 5 menjawab benar yaitu 6 orang (54,5\%) dan didapatkan hasil nilai 0 pada mahasiswa semester 3 dan semester 7. Sementara pada pertanyaan keenam tentang salah dosis, mayoritas mahasiswa semester 7 yang menjawab benar yaitu 13 orang $(41,9 \%)$ dan minoritas mahasiswa semester 5 sejumlah 2 orang $(6,5 \%)$ dengan nilai $\mathrm{p}=0,005$. Kemudian pada pertanyaan ketujuh tentang salah bentuk sediaan dengan nilai $\mathrm{p}=0,000$ yang mayoritas mahasiswa semester 7 menjawab benar yaitu 22 orang $(36,7 \%)$ dan minoritas mahasiswa semester 1 sejumlah 1 orang (1,7\%).

Untuk kasus analisis resep 3 tentang salah lama terapi dan salah indikasi yang melibatkan pasien wanita umur 22 tahun, usia kehamilan 3 bulan dengan diagnosis bacterial vaginosis. Pada pertanyaan kedelapan di kasus analisis resep 3 mahasiswa semester 3 paling banyak menjawab benar yaitu 23 orang $(32,9 \%)$ dengan nilai $p=0,000$. Sedangkan pada pertanyaan kesembilan tentang salah lama terapi dengan nilai $\mathrm{p}=0,000$ yang mayoritas mahasiswa semester 7 yang menjawab benar yaitu 16 orang $(57,1 \%)$ dan minoritas mahasiswa semester 1 sejumlah 2 orang $(7,1 \%)$. Sementara pada pertanyaan kesepuluh tentang salah indikasi, mayoritas mahasiswa semester 3 yang menjawab benar yaitu 15 orang $(62,5 \%)$ dengan nilai $\mathrm{p}=0,000$ dan minoritas mahasiswa semester 1 sejumlah 2 orang $(8,3 \%)$

\section{Distribusi Frekuensi Pendapat Dari Pertanyaan Terbuka Untuk Tingkat Pengetahuan Mahasiswa Terhadap Studi Kasus Tentang Peresepan}

Pada Gambar 2 menunjukkan distribusi frekuensi dari pertanyaan terbuka yang jawabannya berisi tentang pendapat dari mahasiswa program studi pendidikan dokter. Kuliah peresepan diperbanyak dan peresepan disetiap sistem block pembelajaran merupakan pendapat terbanyak dari mahasiswa program studi pendidikan dokter dengan masing-masing perolehan presentase sebesar $37 \%$ dan $35 \%$ dari total populasi ( $n=100$ orang). Sementara untuk latihan peresepan mandiri memiliki perolehan presentase terkecil yaitu $28 \%$ dari total populasi ( $\mathrm{N}=100$ orang).

\section{PEMBAHASAN}

Berdasarkan hasil penelitian, tingkat pengetahuan mahasiswa tentang kesalahan peresepan (PE) tergolong ke kategori tingkat pengetahuan sedang. Hal ini dapat terlihat pada lebih besarnya angka frekuensi responden yang mendapatkan skor di antara rata-rata 3,7-7,1 yang dimasukkan dalam kategori pengetahuan sedang yaitu sebanyak 67 responden $(67 \%)$. Sedangkan sisanya menempati kategori tingkat pengetahuan baik sebanyak 7 responden (7\%) dan buruk sebanyak 26 responden (26\%).

Pada penelitian ini dapat dilihat bahwa tingkat pengetahuan tentang PE terbanyak adalah perempuan yaitu sebanyak 66 responden (66\%). Hasil ini berbeda dengan penelitian Joshi tahun 2017 di India yang mengatakan tidak ada perbedaan jenis kelamin yang signifikan (Joshi, Rymbai dan Hazra, 2017). Perbedaan ini disebabkan karena beberapa hal, seperti wilayah tempat penelitian dan tidak ada hubungan antara jenis kelamin dan prescribing error kemudian jumlah mahasiswa dengan jenis kelamin perempuan dan laki-laki jumlahnya hampir sama. Sedangkan mahasiswa yang belajar di program studi pendidikan dokter Udayana Denpasar jumlah mahasiswa berjenis kelamin perempuan lebih banyak daripada laki-laki.

Pada penelitian tingkat pengetahuan tentang PE dari jumlah umur terbanyak adalah umur 19-20 tahun yaitu 52 responden (52\%). Hasil penelitian ini bertentangan dengan penelitian Warholak 
tahun 2011 di Amerika tentang peresepan yang mengatakan bahwa mahasiswa kedokteran memiliki rata-rata usia diatas 19-20 tahun, lebih tua dibandingkan dengan mahasiswa kedokteran di Universitas Udayana. ${ }^{8}$ Perbedaan hasil penelitian ini disebabkan karena tingkatan mahasiswa kedokteran di Amerika lebih tinggi dibandingkan dengan tingkatan mahasiswa kedokteran di Universitas Udayana.

Berdasarkan hasil pengukuran dari kelompok semester pada penelitian tingkat pengetahuan mahasiswa tentang prescribing errors terbanyak adalah mahasiswa semester 3 dan semester 7 dengan kategori tingkat pengetahuan sedang rerata 3,7-7,1 yang masing-masing berjumlah 22 responden dari jumlah sampel semester 3 sebanyak 25 responden dan semester 7 sebanyak 25 responden. Dari hasil penelitian ini tidak ada penelitian sampai saat ini yang serupa dalam menganalisis tingkat pengetahauan mahasiswa program studi pendidikan dokter terhadap peresepan berdasarkan kelompok semester.

Dapat dilihat pada Tabel 5 bahwa presentase kesalahan resep yang diidentifikasi dengan benar memiliki perbedaan signifikan dimasing-masing kelompok semester. Untuk kasus analisis resep 1 (kesalahan perhitungan pada anak-anak) tentang salah dosis dan bentuk sediaan melibatkan pasien umur 12 tahun dengan diagnosis diare. Dari hasil kasus analisis resep pertama, perbedaan yang paling signifikan antara semester 1, 3, 5, 7 terdapat pada salah bentuk sediaan dengan nilai $\mathrm{p}=0,000$. Dalam penelitian ini mahasiswa semester 3 yang paling mampu mengidentifikasi jenis kesalahan resep sebanyak 21 orang $(39,6 \%)$. Hasil ini berbeda dengan penelitian Warholak tahun 2011 di Amerika mengenai kasus peresepan tentang kesalahan perhitungan pada anak didapatkan mahasiswa kedokteran tidak mampu dalam mengidentifikasi jenis kesalahan resep dengan nilai $\mathrm{p}<0,001{ }^{8}$

Selanjutnya untuk kasus analisis resep 2 (Antibiotik) tentang interaksi obat, salah dosis dan salah bentuk sediaan yang melibatkan pasien umur 30 tahun dengan diagnosis infeksi saluran kemih dan gastritis. Dari hasil kasus analisis resep kedua, mahasiswa semester 3 dan semester 7 memiliki jumlah yang serupa yaitu masing-masing 25 orang $(28,7 \%)$ yang menjawab kasus dengan benar dan memiliki nilai $\mathrm{p}=0,000$ dan untuk jenis kesalahannya terdapat perbedaan signifikan pada interaksi obat dengan nilai $\mathrm{p}=0,006$ yang paling mampu mengidentifikasi jenis kesalahan resep adalah mahasiswa semester 5 yaitu 6 orang (54,5\%). Penelitian dari Poudel tahun 2015 di Nepal menyebutkan bahwa kesalahan interaksi obat juga sering terjadi pada dokter yang telah menuliskan resep sebanyak 8 resep (4,5\%) dari 176 kesalahan resep yang telah dilakukan di apotek rawat jalan Chitwan Medical College. ${ }^{1}$ Sedangkan pada kasus analisis resep kedua ini juga terdapat perbedaan signifikan tentang salah bentuk sediaan dengan nilai $\mathrm{p}=0,000$ yang paling mampu mengidentifikasi jenis kesalahan resep adalah mahasiswa semester 7 yaitu 22 orang (36,7\%). Hasil penelitian ini sedikit berbeda dengan penelitian Poudel tahun 2015 di Nepal yang menyebutkan bahwa kesalahan bentuk sediaan juga sering terjadi pada dokter yang telah menuliskan resep sebanyak 34 resep $(19,3 \%)$ dari 176 kesalahan resep yang telah dilakukan di apotek rawat jalan Chitwan Medical College. ${ }^{1}$

Kemudian dari kasus analisis resep 3 (Antasida) tentang salah lama terapi dan salah indikasi yang melibatkan pasien wanita umur 22 tahun, usia kehamilan 3 bulan dengan diagnosis bacterial vaginosis. Dari hasil kasus analisis resep ketiga, perbedaan yang paling signifikan antara semester $1,3,5,7$ terdapat pada salah lama terapi dengan nilai $\mathrm{p}=0,000$ dan salah indikasi dengan nilai $p=0,000$. Dari kesalahan lama terapi yang paling mampu mengidentifikasi adalah mahasiswa semester 7 yaitu 16 orang $(57,1 \%)$. Penelitian dari Phalke tahun 2011 di India menyebutkan bahwa kesalahan dalam perhitungan lama terapi pada peresepan juga didapatkan hasil yang cukup tinggi sebanyak 368 resep (73,7\%) dari 499 resep yang dianalisis. ${ }^{7}$ Dan selanjutnya, yang paling mampu mengidentifikasi jenis kesalahan indikasi obat dalam kasus peresepan adalah mahasiswa semester 3 yaitu 15 orang $(62,5 \%)$. Hasil penelitian ini bertentangan dengan Poudel yang menyebutkan bahwa kesalahan dalam indikasi obat jumlahnya lebih kecil yaitu 6 resep (3,4\%) daripada jenis kesalahan dosis yang angkanya lebih besar yaitu 69 resep $(39,2 \%)$. Kesalahan yang paling umum terjadi pada peresepan dalam penelitian Poudel di apotek rawat jalan Chitwan Medical College adalah salah dosis, salah bentuk sediaan, interaksi obat dan salah indikasi obat. $^{1}$

Pada Gambar 2 dapat dilihat bahwa frekuensi pendapat dari pertanyaan terbuka untuk tingkat pengetahuan mahasiswa tentang prescribing errors paling banyak pada penelitian ini adalah kuliah peresepan diperbanyak sebesar $37 \%$ dari total populasi 100 mahasiswa. Pertanyaan terbuka ini diberikan untuk mengetahui pendapat dari mahasiswa program studi pendidikan dokter tentang peresepan yang lebih baik untuk kedepannya. Karena prescription (resep) itu berfungsi sebagai perintah tertulis dari dokter yang mencakup petunjuk rinci tentang obat apa dan kepada siapa harus diberikan, formulasi dan dosis, interaksi obat, bentuk sediaan dan untuk berapa lama obat itu harus diminum. ${ }^{6}$ Ketika resep itu tidak sesuai dengan prosedur atau kaidah-kaidah dalam penulisan resep yang benar 
maka akan mengakibatkan kesalahan resep (PE) seperti salah dosis, bentuk sediaan yang salah, interaksi antara kedua obat yang mengakibatkan dosis berlebih dan lain sebagainya. ${ }^{1}$

\section{SIMPULAN}

Pada penelitian ini didapatkan tingkat pengetahuan mahasiswa program studi pendidikan dokter tahun ajaran 2017-2018 di Fakultas Kedokteran Universitas Udayana Denpasar tentang prescribing errors mayoritas berpengetahuan sedang yaitu sebanyak 67 (67\%). Sedangkan responden sisanya berpengetahuan baik sebanyak 7 (7\%) dan berpengetahuan buruk sebanyak 26 (26\%).

\section{SARAN}

Berdasarkan penelitian yang telah dilakukan, dapat disarankan untuk menjadi bahan pertimbangan bagi program studi pendidikan dokter untuk melakukan jam tambahan dalam usaha meningkatkan penguasaan mahasiswa tentang peresepan dari segi penambahan jumlah materi dan jumlah jam khusus.

Kemudian perlu adanya petugas untuk melakukan pengecekan ulang pada resep sebelum diberikan ke pasien, sehingga dapat meminimalisir untuk terjadinya prescribing error.

Selain itu, disarankan agar penelitian tentang tingkat pengetahuan terhadap prescribing error juga terus dilanjutkan dan dilakukan di rumah sakit atau instansi lainnya pada dokter ataupun mahasiswa yang baru lulus preklinik untuk peresepan yang lebih baik lagi.

\section{DAFTAR PUSTAKA}

1. Poudel RS, Piyani RM, Shrestha S, Prajapati A, Adhikari B. Prescription Errors and Pharmacist Intervention at Outpatient Pharmacy of Chitwan Medical College. Journal of Chitwan Medical College. 2015. 5(12): 20-24.

2. Gitawati R. Interaksi Obat dan Beberapa Implikasinya. Media Litbang Kesehatan. 2008. 18(4):175-84.

3. Walker EE. Medication Errors. Imperial Journal of Interdisciplinary Research (IJIR). 2016. 2(5): 2454-1362.

4. Fitriani N. 2015. Skripsi: Gambaran Pengetahuan Tentang Patient Safety Pada Mahasiswa Profesi Keperawatan Angkatan XXII Universitas Muhammadiyah Yogyakarta. Univerisitas Muhammadiyah. Yogyakarta.

5. Gul W. Prescription Error: Preventable medication Error. World Journal of Pharmaceutical Research. 2014. 3(3): 3575-3584.

6. Aronson JK. Medication Errors: What They Are, How They Happen, and How to Avoid Them. Q J Med. 2009. 102: 513-521

7. Phalke DV, Phalke BD, Aarif MMS, Mishra A, Sikchi S, Kalakoti P. Prescription Writing Practices in a Rural Tertiary Care Hospital in Western Maharashtra, India. Australasian Medical Journal. 2011.4(1):4-8.

8. Warholak LT, Queiruga C, Roush, R, Phan H.Medication Error Identification Rates by Pharmacy, Medical, and Nursing Students. Am J Pharm Educ. 2011. 75(2):12-18.

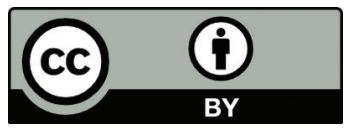

This work is licensed under a Creative Commons Attribution 